Boštjan Kolarič

\title{
Pravna opredelitev zatiranja verske svobode in nasilja nad verskimi skupnostmi
}

\section{The Legal Classification of the Repression of Free- dom of Religion and the Violence against Religious Communities}

Povzetek: Članek podrobneje pravno obravnava pojavno obliko nasilja, imenovano zatiranje verske svobode in nasilje nad verskimi skupnostmi. Pravna obravnava izkazanih oblik nasilja, ki so se izvajale v obdobju komunističnega totalitarnega režima na Slovenskem, in njihov kazenskopravni konec namreč osvetljujemo in napolnjujeta pravni vidik tranzicijske pravičnosti in narodne sprave v Republiki Sloveniji.

Odgovor na znanstveno vprašanje, ali je zatiranje verske svobode in nasilje nad verskimi skupnostmi mogoče pravno opredeliti kot hudodelstvo zoper človečnost, smo dali s pravno opredelitvijo (pravno kvalifikacijo) po klasični subsumpcijski shemi, ki zahteva ugotovitev na način najkasnejšega ujemanja pravno relevantnih dejstev dejanskega stanja in zakonskih znakov pravno relevantne pravne podlage, da lahko to pravno dokončamo, to je: da izvedemo pravno opredelitev kot vrednostno sintezo ali sklep.

Ugotovili smo, da sta preganjanje na verski podlagi kot zatiranje verske svobode in nasilje nad verskimi skupnostmi, ki sta bili opravljeni skupaj s kako drugo izvršitveno obliko hudodelstva zoper človečnost, pravno opredeljeni kot hudodelstvo zoper človečnost. Nasilje nad verskimi skupnostmi, pri katerem je bilo dano ,samo' izvršitveno dejanje preganjanja na verski podlagi, pa je pravno opredeljeno kot sistematična kršitev človekovih pravic in temeljnih svoboščin.

Ključne besede: zatiranje verske svobode, nasilje nad verskimi skupnostmi, pravna opredelitev, hudodelstvo zoper človečnost

Abstract: The article discusses the legal assessment of violence called repression of freedom of religion and violence against religious communities. The legal evaluation of the forms of violence carried out during the communist totalitarian regime in Slovenia, and their criminal legal conclusion illuminate and fill 
the legal aspect of transitional justice and national reconciliation in the Republic of Slovenia.

We provided the answer to the scientific question of whether the repression of freedom of religion and the violence against religious communities can be legally classified as crimes against humanity by carrying out a legal assessment (a legal classification) based on the classic subsumption scheme, which requires establishing the closest match of the legally relevant facts and the legal signs of a lawfully applicable legal norm to determine the legal conclusion, that is the legal classification as a value synthesis or deduction.

We found that the persecution on religious grounds in the form of repression of freedom of religion and violence against religious communities carried out along with some other form of crimes against humanity is legally classified as crimes against humanity. Violence against religious communities that consisted ,only' of the executive action of persecution on religious grounds is legally classified as a systematic violation of human rights and fundamental freedoms.

Keywords: repression of freedom of religion and violence against religious communities, legal classification, crimes against humanity

\section{Uvod}

Nasilje komunističnega totalitarnega režima na Slovenskem v obdobju med letoma 1945 in 1990 je bilo izvedeno v več izkazanih oblikah, ki jih zgodovinopisje deli na: povojne zunajsodne množične umore, koncentracijska in delovna taborišča, izgone prebivalstva, nasilne razlastitve premoženja, politične sodne procese, politične obsojence in politične zapornike ter na zatiranje verske svobode in nasilje nad verskimi skupnostmi. Enako razdelitev izkazanih oblik nasilja uporablja tudi Ustavno sodišče RS (US RS 1992, odst. 8).

Če so zgodovinska dejstva in dogodki v zgodovinopisju dokaj podrobno obravnavani in ugotovljeni, sta ugotavljanje in vrednotenje pravnih vidikov komunističnega totalitarnega nasilja na Slovenskem in uveljavitve prava v izvedeni kazenski odgovornosti storilcev in v obsodbi totalitarnega režima, ki pomenita temelja demokratične in pravne države $z$ delujočo vladavino prava, $v$ slovenski pravni znanosti izrazito zanemarjeni. Prav odsotnost objektivne pravne analize, pravnega vrednotenja in uveljavljanje in uveljavitev prava z ugotovitvijo individualne kazenske odgovornosti storilcev in moralne odgovornosti ter dolžnosti Republike Slovenije v največji meri preprečuje katarzo slovenskega naroda in povzroča vedno nove delitve, namesto doseganja cilja spravnega pomirjenja Slovencev.

Namen prispevka je, s pravno opredelitvijo izkazane oblike nasilja zatiranje verske svobode in nasilja nad verskimi skupnostmi pripomoči k uveljavljanju in utrjevanju vladavine prava ter s preganjanjem in kaznovanjem storilcev prispevati k spravi v Republiki Sloveniji. Uveljavitev vladavine prava namreč pomeni najpo- 
membnejši element mehanizma tranzicijske pravičnosti v posttotalitarnih družbah, ki bistveno prispeva k spravi in k skladnemu civilizacijskemu razvoju ter utrjevanju vladavine prava in demokracije.

De facto še ne popolnoma raziskave in de iure neopredeljene oblike množičnega in sistematičnega nasilja in s tem kršenja človekovih pravic in temeljnih svoboščin namreč ležijo kot zgodovinska mora nad slovenskim narodom in povzročajo travme ter politične in osebne delitve.

V prispevku bomo pravno opredelili izkazano obliko nasilja kot zatiranja verske svobode in nasilja nad verskimi skupnostmi s pravno opredelitvijo (pravno kvalifikacijo) po klasični subsumpcijski shemi. Ta shema zahteva ugotovitev pravno relevantnih dejstev dejanskega stanja in zakonskih znakov pravno relevantne pravne podlage v obliki splošnega in abstraktnega pravnega pravila, ki pomeni zgornjo premiso (lat. praemissa maior), konkretno izkazano dejansko stanje pa spodnjo premiso (lat. praemissa minor) pravnega silogizma. Če so v abstraktni pravni normi opisani znaki uresničeni v dejanskem stanju oziroma ko se pravno relevantna dejstva in abstraktno (zakonsko) dejansko stanje najtesneje ujamejo, lahko to pravno dokončamo, to je: izvedemo pravno opredelitev kot vrednostno sintezo ali sklep (lat. conclusio). Prispevek tako prek analize ujemanja zgodovinskega dejanskega stanja in pravnih zakonskih znakov hudodelstev zoper človečnost povezuje znanstveni področji zgodovine in prava.

Znanstveno vprašanje, ki ga zastavljamo. je, ali je nasilje v obdobju komunističnega totalitarizma na Slovenskem, ki je bilo izvedeno v izkazani obliki zatiranja verske svobode in nasilja nad verskimi skupnostmi, mogoče pravno opredeliti kot hudodelstvo zoper človečnost.

Ker za pravno opredelitev zadostujejo pravno relevantna dejstva, smo opravili sintezo zgodovinskih dejstev obravnavane izkazane oblike nasilja, ki jih pomenijo predvsem:

- število žrtev in njihov družbeni ali pravni status,

- obseg nasilja in njegova sistematičnost,

- obstoj pravne podlage ali načrta nasilja,

- dokazi o morebitnem zavedanju storilca o okoliščinah nasilja,

- dokazi o morebitnem posebnem namenu storilca po uničenju varovane skupine.

Na podlagi najtesnejšega ujemanja konkretnega in zakonskega dejanskega stanja smo z metodo silogističnega sklepanja izvedli pravno posledico v obliki pravne opredelitve zatiranja verske svobode in nasilja nad verskimi skupnostmi v obdobju komunističnega totalitarizma na Slovenskem.

\section{Hudodelstva zoper človečnost}

Rimski statut stalnega Mednarodnega kazenskega sodišča (MKS), ki je stopil v veljavo po 60 ratifikacijah dne 1 . julija 2002, ko je bilo sodišče tudi formalno ustanovljeno in pristojno za preganjanje in kaznovanje storilcev mednarodnih hudo- 
delstev, v prvem odstavku 7. člena definira hudodelstva zoper človečnost kot »katerakoli od naslednjih dejanj, ki so sestavni del širokega ali sistematičnega napada na civilno prebivalstvo ob vednosti storilca, da gre za tak napad « ter taksativno našteva takšna dejanja:

»umor; iztrebljanje; zasužnjevanje; deportacija ali prisilna preselitev prebivalstva; zapor ali drug odvzem prostosti ob kršitvi temeljnih pravil mednarodnega prava; mučenje; posilstvo, spolno suženjstvo, vsiljena prostitucija, prisilna nosečnost, prisilna sterilizacija ali katera koli druga oblika primerljivo hudega spolnega nasilja; preganjanje kakšne prepoznavne skupine ali skupnosti zaradi političnih, rasnih, narodnih, etničnih, kulturnih, verskih razlogov, razlogov, povezanih s spolom, kot je določeno $v$ tretjem odstavku, ali drugih razlogov, ki so po mednarodnem pravu na splošno priznani kot nedopustni, če je takšno preganjanje povezano z drugim dejanjem, navedenim $v$ tem odstavku, ali s katerim koli drugim kaznivim dejanjem iz pristojnosti sodišča; prisilno izginotje oseb; apartheid; druga podobna nečlovečna dejanja, ki naklepno povzročajo veliko trpljenje ali hude telesne poškodbe ali okvare duševnega ali telesnega zdravja.»

Drugi odstavek 7. člena Rimskega statuta MKS pa obširneje pojasnjuje najpomembnejše pojme iz prvega odstavka.

Rimski statut MKS tako določa naslednje elemente oziroma zakonske znake hudodelstev zoper človečnost, ki jih mora izpolniti dejansko stanje, da ga lahko opredelimo kot hudodelstvo zoper človečnost, in ki so postali del običajnega mednarodnega prava:

1. fizični element oziroma izvršitvena oblika dejanskega stanja (lat. actus reus): "umor, pokol, mučenje, iztrebljanje, zasužnjevanje, izvajanje poskusov, zunajsodno kaznovanje, deportacija, ugrabitev, neupravičen odvzem prostosti, suženjstvo, kanibalstvo, mučenje, posilstvo, preganjanje na politični, verski ali rasni podlagi in druga nečloveška ravnanja«;

2. kontekstualni element dejanskega stanja: "če so izvršena kot sestavni del širokega ali sistematičnega napada na civilno prebivalstvo«;

3. mentalni element storilca dejanskega stanja (lat. mens rea): "ob vednosti storilca, da gre za tak napad«.

Tako Rimski statut MKS ponuja najširši nabor kriminalnih dejanj, ki lahko pomenijo hudodelstva zoper človečnost, če so sestavni del velikega ali sistematičnega napada na civilno prebivalstvo ob vednosti storilca, da je to takšen napad, in hkrati ne zahteva, da je napad storjen na nacionalni, politični, etnični, rasni ali verski podlagi (razen v izvršitvenem dejanju preganjanja kake prepoznavne skupine ali skupnosti, ki mora biti opravljeno v povezavi s katerim drugim naštetim izvršitvenim dejanjem ali katerim drugim hudodelstvom, za katero je pristojno MKS). (Cassese 2002, 376)

Rimski statut MKS pomeni zadnje soglasje mednarodne skupnosti s 124 državami članicami statuta in tako danes velja kot najbolj avtoritativna mednarodno 
pravna opredelitev pojma hudodelstva zoper človečnost. Vsebina 7. člena Rimskega statuta MKS namreč dejansko odseva 6. (c) člen Nürnberške listine Mednarodnega vojaškega tribunala iz leta 1945, katere načela so postala del običajnega mednarodnega prava, in v najširšem smislu odseva tudi splošna pravna načela civiliziranih narodov. Ker pa se stricto sensu Rimski statut MKS ne more uporabljati za pravno opredelitev dejanskih stanj, ki so bila storjena pred 1. julijem 2002, ko je statut stopil v veljavo, to onemogoča ex post facto preganjanje in je tako uporabljiv strogo prospektivno. (Bourgon 2002, 543)

Domača pravna definicija hudodelstev zoper človečnost je dana v Kazenskem zakoniku Republike Slovenije. Čeprav v Sloveniji vse do leta 2008, ko je bila sprejeta novela Kazenskega zakonika Republike Slovenije, nismo poznali domačih pravnih pravil o hudodelstvih zoper človečnost, na tem področju ni obstajala pravna praznina, saj so se izvršitvena dejanja hudodelstev zoper človečnost preganjala po že obstoječih pravnih pravilih o vojnem hudodelstvu, če so bila dejanja storjena v vojnem času ali oboroženem spopadu. Če pa so bila izvršitvena dejanja hudodelstev zoper človečnost storjena v obdobju miru, so organi pregona in kaznovanja storilcev uporabljali inkriminacijo splošnih dejanj (umor, telesne poškodbe, protipravni odvzem prostosti). Zakonodajalec pa je to pomanjkljivost odpravil na način vrinjenja, saj je $v$ člene, ki so že obravnavali vojna hudodelstva zoper civilno prebivalstvo ter ranjence in bolnike vrinil naslednje: " /.../ ali pri izvajanju ali v podporo politiki kakšne države ali organizacije, kot velik del sistematičnega napada /.../.« (Korošec 2009, 19)

Kazenski zakonik Republike Slovenije (KZ-1) je leta 2008 domačo pravno opredelitev hudodelstev zoper človečnost predložil v 101. členu, v katerem je vsebinsko povzel besedilo 7. člena Rimskega statuta MKS tako, da je združil besedila prvega in drugega interpretativnega odstavka v eni alineji. Posebnost je nastala pri alineji o preganjanju, ki jo je KZ-1 še bolj zožil kakor Rimski statut, ki veže to izvršitveno dejanje alternativno na katerokoli drugo izvršitveno dejanje iz 7. člena ali na kako drugo dejanje iz pristojnosti MKS, to pa omejuje njegov namen. (Ambrož et al. 2012, 196). KZ-1 namreč zahteva, da morajo biti poleg izvršitvenega dejanja preganjanja kumulativno izpolnjeni še zakonski znaki kakega drugega izvršitvenega ravnanja hudodelstva zoper človečnost in še zakonski znaki genocida (100. člen), vojnih hudodelstev (102. člen) ali agresije (103. člen). „Na podlagi jezikovne razlage je dopustna zgolj kumulativna uporaba vseh pogojev in ne alternativna. Takšno kumulativno predpisovanje kaznivih dejanj je zelo omejujoče, zlasti pa je v nasprotju z Rimskim statutom. « (Zgaga 2009, 18-19)

\subsection{Prvi zakonski znak hudodelstev zoper človečnost}

Prvi zakonski znak hudodelstev zoper človečnost, ki ga določata relevantni pravni določbi 7. člena Rimskega statuta MKS in 101. člena KZ-1 in dodatno pojasnjuje sodna praksa mednarodnih kazenskih sodišč, je katerokoli od naslednjih izvršitvenih dejanj (lat. actus reus): umor, iztrebljanje, zasužnjevanje, deportacija ali prisilna preselitev prebivalstva, mučenje, zapor ali kak drug odvzem prostosti ob kršitvi temeljnih pravil mednarodnega prava, prisilno izginotje oseb, preganjanje, druga podobna nečloveška ravnanja. 
Preganjanje sodna praksa opredeljuje kot »dejanja proti posamezniku zaradi njegove pripadnosti določeni rasni, verski ali politični skupini « (MKSJ 2004a, odst. 235), pri tem pa »preganjanje nujno ne zahteva fizičnega elementa, pri čemer se diskriminatorna podlaga, tj. politična, rasna ali verska, razume kot vzajemno izključujoča ", pove torej: ni treba, da je dana kumulativno (1997, odst. 707), če "storilec preganjanja ni prvenstveno ciljal na posameznike, ampak na pripadnost posebni rasni, verski ali politični skupini巛 (2004a, odst. 244), in Rimski statut MKS $v$ drugem odstavku 7. člena pojasnjuje preganjanje kot

»naklepno in hudo kratenje temeljnih pravic v nasprotju z mednarodnim pravom zaradi prepoznavne lastnosti skupine ali skupnosti in sicer zaradi političnih, rasnih, narodnih, etničnih, kulturnih, verskih razlogov, razlogov povezanih s spolom, ali drugih razlogov, ki so po mednarodnem pravu splošno priznani kot nedopustni, če je takšno preganjanje povezano z drugim dejanjem, navedenim v tem odstavku, ali katerim koli drugim kaznivim dejanjem iz pristojnosti sodišča."

\subsection{Drugi zakonski znak hudodelstev zoper človečnost}

Drugi zakonski znak hudodelstev zoper človečnost, ki ga določata relevantni pravni določbi 7. člena Rimskega statuta MKS in 101. člena KZ-1 in dodatno pojasnjuje sodna praksa mednarodnih kazenskih sodišč OZN in MKS, je kontekstualni element izvršitvenega dejanja, ki zahteva, da je izvršitveno dejanje »izvršeno kot sestavni del širokega ali sistematičnega napada proti kateremukoli civilnemu prebivalstvu«. Terminološko opredelitev »izvršeno kot sestavni del širokega ali sistematičnega napada « pojasnjuje drugi odstavek 7. člena Rimskega statuta MKS kot „večkratno izvršitev dejanj iz prvega odstavka zoper civilno prebivalstvo pri izvajanju ali v podporo politiki kakšne države ali organizacije, ki imata takšne cilje».

Pri hudodelstvih zoper človečnost mora biti napad širok ali sistematičen, sem se ne prištevajo individualna dejanja obtoženih (MKSJ 2004b, odst. 94). Pojem ,širok' zadeva velik obseg napada in število žrtev (2005, odst. 183). "Koncept, široko razširjen' bi lahko definirali kot množično in pogosto delovanje v velikem obsegu, ki se izvršuje kolektivno z veliko težo in je usmerjeno zoper večje število žrtev. Koncept ,sistematičen' bi lahko definirali kot skrbno organiziran, ki sledi urejenemu vzorcu na podlagi skupne politike in vključuje bistveno količino javnih in zasebnih virov. Pri tem ni potrebno, da je ta politika uradna politika države. Kljub temu pa mora obstajati vnaprej pripravljen načrt ali politika. " (1998, odst. 579580) Zato "so iz hudodelstev zoper človečnost izključena tista dejanja, ki niso storjena kot del širše politike ali načrta" (1999, odst. 124).

Nasprotno MKSJ v svojih odločitvah ni zahtevalo obstoja politike ali načrta pri izvršitvi hudodelstev zoper človečnost. »Napad ne potrebuje podpore z obstojem načrta ali politike. « (2004a, odst. 120) »Obstoj načrta ali politike napada je lahko dokazno relevanten, ni pa pravni element zločina. « (2004b, odst. 100, 126)

Sodna praksa je sistematičnost dodatno pojasnila kot: "podpornik (agent) sistema ne rabi delovati sistematično; dovolj je, če je njegovo posamezno dejanje 
bilo povezano s sistemom ter je tako izgubilo naravo posamičnega primera; dejanja, storjena na sistematičen način, kot praksa držav s strani izvrševalcev ideološke hegemonije. « (Cassese 2002, 357-358)

Opredelitev ,napad proti civilnemu prebivalstvu' zožuje področje pojma ,širok ali sistematičen napad', pri tem pa drugi odstavek 7. člena Rimskega statuta MKS dodatno opredeljuje, da napad pomeni »ravnanje, ki vključuje večkratno izvršitev dejanj iz prvega odstavka zoper civilno prebivalstvo pri izvajanju ali v podporo politiki kakšne države ali organizacije, ki imata takšne cilje.«

\subsection{Tretji zakonski znak hudodelstev zoper človečnost}

Tretji zakonski znak hudodelstev zoper človečnost, ki ga določata relevantni pravni določbi 7. člena Rimskega statuta MKS in 101. člena KZ-1 in dodatno pojasnjuje sodna praksa mednarodnih kazenskih sodišč OZN in MKS, je zahtevani mentalni element izvršitvenega dejanja (lat. mens rea), pravno opredeljen kot »vednost storilca, da gre za tak napad«, ki zahteva vedenje storilca o širokem ali sistematičnem napadu zoper civilno prebivalstvo. Mentalni naklep storilca je najteže dokazljiv zakonski znak hudodelstva zoper človečnost.

Tako je MKSR mentalni naklep pojasnilo, kot da je ustorilec moral vedoma storiti hudodelstva zoper človečnost v tem smislu, da je mogel razumeti celoten kontekst svojih dejanj. /.../ Storilec je moral vedeti, da je njegovo dejanje del širokega ali sistematičnega napada na civilno prebivalstvo in izvrševanja neke vrste politike ali načrta. " (MKSR 1999, odst. 133-134) "Storilec mora vedeti, da poteka napad na civilno prebivalstvo, in mora vedeti, da so njegova dejanja del napada ali vsaj tveganje, da bi bila njegov del. Vendar to ne pomeni, da mora poznati podrobnosti napada. Zadostuje, da je s svojimi dejanji ali funkcijo, ki jo je voljno sprejel, vedoma sprejel tveganje sodelovanja v izvršitvi napada. « (2002, odst. 59)

\section{Pravna opredelitev zatiranja verske svobode in nasilja nad verskimi skupnostmi}

Po koncu druge svetovne vojne si je Komunistična partija Slovenije (KPS), da bi preoblikovala družbeni sistem v skladu z novim svetovnim nazorom komunizmom, prizadevala, z različnimi sredstvi uveljaviti marksistično ateistično ideologijo. $V$ ta namen je poskušala omejiti vpliv verskih skupnosti, posebno katoliške Cerkve, ki je bila daleč največja in pomembno vpeta v slovenski prostor, pa tudi vpliv manjših nekatoliških verskih skupnosti in jih hkrati nadzorovati.

Po vojni je partija , priredila' celo vrsto duhovniških in redovniških procesov, to so bili božični proces, jezuitski proces, Rožmanov proces, proces proti frančiškanom, Leničev proces, Bitenčev proces, proces proti Katoliški akciji, procesi proti lazaristom, magdalenkam, frančiškankam (Griesser Pečar 2005). Za razumevanje povojnega odnosa komunističnih oblasti do Cerkve in do verskih skupnosti se je treba ozreti na medvojno obdobje oziroma medvojno obdobje revolucionarnega 
nasilja nad pripadniki katoliškega tabora (Hančič 2015, 649-657).

V skladu z želeno marksistično ateistično ideologijo namreč religija ni imela mesta v komunističnem režimu. To pooseblja izjava Franca Leskoška - Luka na seji Okrajnega komiteja Zveze komunistov Slovenije v Celju 28. junija 1954: »Mi smo nasprotniki vere. Mi vemo, da je vera šašava stvar. To je strašilo za ljudi. Vera v 20. stoletju ne spada več v našo stvarnost. To je stvar, ki je bila pred 500 leti, danes pa je neumnost. « (Mikola 2012, 343) Enako pove Priročnik za delo Milice na področju varstva ustavne ureditve iz leta 1985, ki ga je izdal Republiški sekretariat za notranje zadeve, ko so posebne naloge v zvezi s spremljanjem Cerkve in njenih duhovnikov dobile postaje Ljudske milice (359).

Za komunistično oblast na Slovenskem je bila Cerkev notranji sovražnik številka ena, ker je ostala edina organizirana sila zunaj partije. Zato jo je komunistična oblast skušala - če že ne uničiti, pa vsaj podjarmiti. (Griesser Pečar 2013, 2) Oblika preganjanja verskih skupnosti so bili tudi montirani politični sodni procesi. Zapisniki politbiroja CK KPS od leta 1945 do leta 1952 potrjujejo izvajanje montiranih političnih procesov proti pripadnikom Cerkve. Na seji CK KPS dne 25. decembra 1945 je minister za notranje zadeve Ivan Maček - Matija predložil organizacijsko-politično poročilo o sodnem načinu obračunavanja z duhovščino in svojo namero glede nadaljnjega političnega pritiska proti Cerkvi pojasnil z besedami: „Mi bomo v bližnji bodočnosti zaprli nekoliko farjev, kajti imamo dovolj podatkov, da bodo lahko obsojeni. « (Ščavničar 2016, 113)

Analiza ugotovljenih pravno relevantnih dejstev, okoliščin in dokazov izvršitve nasilja pri zatiranju verske svobode in nasilja nad verskimi skupnostmi, ki pomenijo kršitve človekovih pravic in temeljnih svoboščin, kaže, da so bili opravljeni v vsaj eni obliki izvršitvenega dejanja hudodelstev zoper človečnost, to je: kot preganjanje na verski podlagi.

Drugi element oziroma zakonski znak hudodelstev zoper človečnost, ki zahteva, da je izvršitveno dejanje opravljeno kot sestavni del širokega ali sistematičnega napada proti kateremukoli civilnemu prebivalstvu, to pa pomeni večkratno izpeljavo izvršitvenih dejanj hudodelstev zoper človečnost, zoper civilno prebivalstvo pri izvajanju ali v podporo politike kake države ali organizacije s takšnimi cilji, se potrjuje $v$ široki in sistematično organizirani naravi nasilnih dejanj:

- Od maja 1945 do leta 1961 je bilo obtoženih 429 duhovnikov od povprečno nekaj manj kakor 1000, 339 jih je bilo kaznovanih z zaporno kaznijo, 73 pa je bilo denarno kaznovanih; 9 duhovnikov, salezijanski pomočnik in neka usmiljenka so bili obsojeni na smrt, 4 duhovniki so bili usmrčeni. Sodbe so pogosto vsebovale zaplembo vseh premičnin in nepremičnin. Zaradi obsodbe posameznikov je bilo zaseženo premoženje redov, to pa potrjuje dejstvo, da so bile kazni nesorazmerne. Najbolj znani politični montirani sodni procesi, v katere so bili vključeni duhovniki, so bili božični proces, Rupnikov/Rožmanov proces in Bitenčev proces. $V$ teh procesih so bile obtožnice in sodbe skonstruirane, sestavljene na podlagi lažnega gradiva ali pričevanj, predlogi zagovornikov nemočni, prič in dokumentov v prid obtoženca pa sodišče ni upoštevalo. Številni 
sakralni objekti - cerkve, kapele, znamenja, križi, pokopališča - so bili onečaščeni, nasilno porušeni ali rušeni pod kako ,strokovno' pretvezo, posebno po prekinitvi diplomatskih odnosov z Vatikanom leta 1952. Dodatno je bila Cerkev kot institucija pod krinko ,ločitve cerkve in države' izločena iz javnega življenja in zaznamovana z močno protiversko in proticerkveno propagando. Da bi partija ločila duhovnike od škofov, izigrala vodstva škofij med seboj in onemogočila vpliv Vatikana, je politična oblast s podporo SDV dne 20. septembra 1949 ustanovila Cirilmetodijsko društvo katoliških duhovnikov. (Griesser Pečar, 2010) Cirilmetodijsko društvo so samo navidezno ustanovili ,napredni' duhovniki, dejansko pa je za njimi stala komunistična oblast $(2017,435)$.

- Med letoma 1951 in 1961 je bilo upravno kaznovanih 1411 duhovnikov na skupaj 1450 dni zapora (Griesser Pečar, 2005). Po podatkih s seznama obsojenih duhovnikov iz Nadškofijskega arhiva Ljubljana je bilo do leta 1951 na Slovenskem obsojenih 185 pripadnikov Cerkve, od tega v mariborski škofiji 62, to je pomenilo 33 odstotkov vseh sodb. Med njimi je bila v 14 primerih izrečena tudi kazen zaplembe premoženja. (Ščavničar 2016, 111-127)

- Med letoma 1945 in 1955 je bilo upravno kaznovanih 1033 duhovnikov, od tega 969 z denarnimi kaznimi. Do leta 1961 je bilo po statistiki najmanj 1450 predstavnikov Cerkve kaznovanih upravno in denarno in 95 z zaporno kaznijo. (Griesser Pečar 2005, 635-636)

- Cerkev je za tedanjo oblast pomenila ,izrazitega razrednega sovražnika', zato so jo nameravali ideološko in ekonomsko uničiti, predvsem z zaplenitvijo cerkva in cerkvenih veleposestev in z diskreditacijo duhovnikov v sredstvih javnega obveščanja, ko so članki o sodnih procesih, v katerih so bili obsojeni duhovniki, izstopali po velikosti in poudarjenosti, poročanje pa je bilo pristransko, enostransko in zaničljivo (Ščavničar 2016, 112). Juhant ugotavlja, da se je marksistično postavljanje sveta na glavo začelo s propagandno vojno zoper nosilce dotedanjega krščanskega duhovnega izročila, ki je skušala postaviti na laž pomen teh ljudi in njihovih duhovnih korenin, temu pa je sledila dejanska nasilna odstranitev teh nosilcev (likvidacije) in z njo povezana oblast terorja (Juhant 2016, 132).

Sistematičnost se potrjuje $v$ organizirani naravi političnih sodnih procesov proti Cerkvi, duhovnikom in drugim verskim skupnostim. Represija KPS se namreč ni omejevala samo na katoliško Cerkev in na njeno duhovščino, ampak so ji bile v enaki meri izpostavljene tudi preostale verske skupnosti; najhuje so bili preganjani pripadniki Jehovovih prič in baptisti, prizaneseno pa ni bilo niti pravoslavni in evangeličanski Cerkvi. (Mikola 2012, 359-367) Največji pritisk na nekatoliške verske skupnosti se je izvajal od leta 1948 do leta 1953, pri tem pa je osrednjo vlogo odigrala SDV. Tako so leta 1948 potekali sodni procesi proti pripadnikom evangeličanske in pravoslavne Cerkve in proti pripadnikom baptistične verske skupnosti. Največ sodnih postopkov je bilo proti pripadnikom Jehovovih prič leta 1948, leta 1949 in leta 1952, pritisk pa se je nadaljeval tudi v šestdesetih in sedemdesetih letih, zaradi ugovora vesti verskega prepričanja - odklanjanje orožja in odklanjanje služenja vojaškega 
roka. Na dan 15. marca 1987 je bilo v zaporih Ljubljana in Rogoza Maribor zaprtih še devet pripadnikov Jehovovih prič. Mnogi so bili večkrat obsojeni in zaprti zaradi istega kaznivega dejanja. (Strajnar 2014, 119-127) Sistematičnost se potrjuje tudi v različnih oblikah zatiranje verske svobode in nasilja nad verskimi skupnostmi. Večinoma je to potekalo prek kazenskega sodstva z metodami zrežiranih političnih procesov, na katerih so jim očitali protidržavno politično delovanje, njihov namen pa naj bi bilo zrušenje obstoječe družbene ureditve z nasiljem. Tako je KPS za uničenje verskih skupnosti na Slovenskem sistematično izvedla naslednje ukrepe:

- preimenovanje okoli sto petdeset slovenskih krajev, ki so dobili ime po katoliških svetnikih, na podlagi Zakona o imenih naselij in označb trgov, ulic in hiši iz leta 1948,

- pritiske na verujoče učitelje in profesorje in preostale državne uslužbence,

- zbiranje podatkov o učencih, ki so se udeleževali verouka,

- ustanovitev posebne komisije za vprašanje vere pri partijskih komitejih,

- izločitev teološke fakultete iz univerze,

- politične sodne procese proti katoliškim duhovnikom,

- agrarno reformo, po kateri so smele verske ustanove obdržati 10 ha posestev, izjemoma do 30 ha obdelovalne zemlje in do 30 ha gozdov,

- uničevanje in skrunjenje sakralnih objektov in fizične napade na duhovnike, $s$ soglasjem partije,

- izvajanje hišnih preiskav, stanovanjsko utesnjevanje in brisanje z volilnih list,

- ukinjanje cerkvenih šol, omejevanje verouka in verskega tiska,

- odpuščanje sester iz šol in bolnišnic,

- pridobivanje zaupnikov SVD med katoliškimi in nekatoliškimi verskimi skupnostmi. (Mikola 2012, 343-367; Griesser Pečar 2005; 2010)

Vpliv političnega pritiska na katoliško Cerkev in zatiranja verske svobode so občutili tudi verniki, ki so morali izražanje veroizpovedi umakniti v zasebno sfero. Nanje so najbolj vplivali sovražni govor, diskriminacija na področju izobraževanja in dela in prepoved javnega izražanja vere. Zaradi vsega tega lahko $v$ sedemdesetih letih že opazimo učinke sekularizacije in močno upadanje deleža vernih. (Piškurić 2018, 592-607)

Ugotavljamo, da se zahtevani kontekstualni element hudodelstev zoper človečnost potrjuje $v$ navedenih pravno relevantnih dejstvih, okoliščinah in dokazih, ki kažejo na širšo naravo hudodelstev, velik obseg napada in števila žrtev, to pa je v pravni teoriji razumljeno kot množično in pogosto delovanje v velikem obsegu, ki se izvršuje kolektivno $z$ veliko težo in je usmerjeno zoper večje število žrtev. Sistematičnost se potrjuje $v$ organizirani naravi kršitve nasilja $v$ obdobju komunističnega totalitarizma, ki ga je izvajala KPS kot dejanska oblast na Slovenskem. Prav tako ugotavljamo, da so bile kršitve človekovih pravic in temeljnih svoboščin storjene v izvajanju politike diskriminacije ali preganjanja prepoznavne skupine na verski in razredni podlagi. Obenem so bile žrtve deležne sistematičnega spodkopavanja človeškega dostojanstva, to pa kaže, da imamo lahko ta dejanja za del celostne politike in doslednega vzorca nečlovečnosti. Nečlovečnost napada namreč zahteva, da mora 
biti izvršitvena oblika nasilja nečlovečne narave in pomena, ki povzroča veliko trpljenje ali hudo telesno poškodbo ali škodo za duševno ali fizično zdravje.

Ugotavljamo, da sta bili zatiranje verske svobode in nasilje nad verskimi skupnostmi izvedeni kot del velikega napada na civilno prebivalstvo in da je zahteva po izpolnitvi terminološke opredelitve "proti kateremukoli civilnemu prebivalstvu« izpolnjena, saj je bil primarni objekt napada civilno prebivalstvo.

Ugotavljamo, da se v izkazani obliki nasilja, imenovani zatiranje verske svobode in nasilje nad verskimi skupnostmi, zahtevani mentalni element hudodelstev zoper človečnost potrjuje na podlagi ugotovljenih pravno relevantnih dejstev, okoliščin in dokazov izvršitve nasilja in obstoja različnih pravnih podlag, po katerih so organizirali vzpostavitev in delovanje različnih oblik izkazanih oblik nasilja, to pa pomeni, da so se storilci, ki so bili agenti sistema glede na svoj položaj, mogli in morali zavedati širšega konteksta napadov in dejstva, da so njihova dejanja del napadov. To izhaja:

- iz sprejetja „Zakona o kaznivih dejanjih zoper narod in državo“ iz leta 1946, po katerem je bila kaznovana večina duhovnikov do julija 1951 (Griesser Pečar 2005);

- iz sprejetja „Zakona o prekrških zoper javni red in mir“ iz leta 1949, ko so mnogim duhovnikom prostost odvzeli tudi upravni organi za notranje zadeve pri okrajnih in mestnih ljudskih oblasteh, z izrekanjem tako imenovanih administrativnih (upravnih) kazni oziroma ,varstvenih ukrepov'.

To ugotavlja tudi Ustavno sodišče Republike Slovenije, ki pravi,

»da so bili jugoslovanski državljani, ki so ostali v državi, desetletja podvrženi trajnemu in sistematičnemu ogrožanju človekovih pravic in temeljnih svoboščin v tedanjem družbenopolitičnem sistemu, velja v polni meri tudi za Cerkev. Posebej velja opozoriti, da pravni in dejanski položaj verskih skupnosti v tedanjem sistemu ni bil določen samo s splošno znanimi predpisi, ampak je bil njihov položaj, še posebej pa položaj Rimskokatoliške cerkve v Sloveniji podrobneje definiran s strogo zaupnimi, skrivnimi internimi navodili, ki so tedaj skupaj z drugimi skrivnimi predpisi tvorila paralelni skrivni pravni sistem. /.../ Oživljanje proticerkvene agitacije in poskusi stigmatizacije Cerkve kot fevdalne gosposke in tujka na Slovenskem pomenijo v bistvu perpetuiranje ideološko političnih stališč iz dokumentov nekdanje tajne politične policije o Cerkvi kot permanentnem notranjem sovražniku in generiranje novih umetno ustvarjenih nasprotij, kar vodi $\mathrm{k}$ protiustavnemu spodbujanju nestrpnosti do Cerkve v nasprotju z 63. členom Ustave.« (Ustavno sodišče Republike Slovenije 1996, tč. 35)

Dodatni pogoj, da lahko izvršitveno dejanje preganjanja opredelimo kot hudodelstvo zoper človečnost, je, da mora biti po Rimskem statutu MKS to dejanje vezano alternativno na katerokoli drugo izvršitveno dejanje hudodelstev zoper človečnost ali katero drugo dejanje iz pristojnosti MKS, po KZ-1 pa kumulativno povezano še s katerim drugim izvršitvenim dejanjem hudodelstev zoper človečnost 
in z genocidom, vojnim hudodelstvom ali agresijo.

Tako preganjanje na verski podlagi kakor zatiranje verske svobode in nasilje nad verskimi skupnostmi, ki so bila opravljena skupaj s kako drugo izvršitveno obliko hudodelstev zoper človečnost, kakor so na primer ,umori‘ (umor Lojzeta Grozdeta 1. januarja 1943 itd.), »zapor ali drug strog odvzem prostosti ob kršitvi temeljnih pravil mednarodnega prava « (zapiranje Jehovovih prič itd.), »mučenje, ki pomeni naklepno povzročitev hude bolečine, telesnega ali duševnega trpljenja osebi, ki jo je storilec pridržal, pri čemer mučenje ne vključuje bolečine ali trpljenja, ki je izključno posledica izvrševanja zakonitih sankcij ali je z njimi povezano« (zažig škofa Antona Vovka 20. januarja 1952, politični sodni procesi proti duhovnikom itd.), pravno opredeljujemo kot hudodelstva zoper človečnost.

Na splošno pa zatiranje verske svobode in nasilje nad verskimi skupnostmi kot preganjanje na verski podlagi pravno opredeljujemo kot sistematične kršitve človekovih pravic in temeljnih svoboščin, kakor so pravica do življenja in telesne nedotakljivosti, človekovega dostojanstva, pravica do osebne svobode, svobode govora in spoštovanja verskega prepričanja, pravica do svobode mišljenja, vesti in vere, in kot kršitve temeljnih sodnih pravic, kamor sodi predpostavka poštenega postopka. Razglasitev kolektivnih kazni in nedoločnost inkriminiranih dejanj sta bili v nasprotju z že takrat veljavnim 50. členom „Haškega pravilnika o vojskovanju na kopnem“, ki prepoveduje kaznovanje celotnega prebivalstva zaradi dejanj posameznikov. V nekaterih primerih, ko so storilci pozivali k sovraštvu, diskriminaciji ali nasilju na verski podlagi, lahko govorimo tudi o sovražnem govoru.

\section{Kratice}

CK KPS- Centralni komite Komunistične partije Slovenije.

KPS - Komunistična partija Slovenije.

KZ-1 - Kazenski zakonik Republike Slovenije 2008.

MKS - Mednarodno kazensko sodišče.

MKSJ - Mednarodno kazensko sodišče za bivšo Jugoslavijo 1997/2002/2004/2004a/2005.

MKSR - Mednarodno kazensko sodišče za Ruando 1998/1999.

OZN - Organizacija združenih narodov.

SDV - Služba državne varnosti.

\section{Reference}

Pravni viri

Kazenski zakonik Republike Slovenije. 2008. V: Uradni list RS, št. 50/12. PISRS, 4. 6. http:// pisrs.si/Pis.web/pregledPredpisa?id=ZAKO5050 (pridobljeno 28. 8. 2020).

Mednarodno kazensko sodišče za bivšo Jugoslavijo. 1997. Tožilec proti Tadić. IT-94-1. 7. 5.
---. 2002. Tožilec proti Krnojelcu. IT-97-25-T. 15. 3.

- - . 2004a. Tožilec proti Blaškiću. IT-95-14-T. 3. 3.

- - 2004b. Kordić in Čerkez. IT-95-14/2. 17. 12.

---. 2005. Limaj et al. IT-03-66. 30. 11.

Mednarodno kazensko sodišče za Ruando. 1998. Tožilec proti Akayesuju. ICTR-96-4-T. 2. 9.

- - - 1999. Tožilec proti Kayishemi in Ruzindani. 
ICTR-95-1-T. 21. 5.

Ustavno Sodišče Republike Slovenije. 1992. Opr. št. I, 102, U-I-69/92-30.

- - 1996. Opr. št. V, 174, U-I-107/96.

\section{Druge reference}

Ambrož, Matjaž, Ljubo Bavcon, Zvonko Fišer, Damjan Korošec, Vasilka Sancin, Liljana Selinšek in Mirjam Škrk, ur. 2012. Mednarodno kazensko pravo. Ljubljana: GV Založba.

Bourgon, Stéphane. 2002. Jurisdiction Ratione Temporis. V: Antonio Cassese, Paola Gaeta in John R.W.D. Jones, ur. The Rome Statute of the International Criminal Court: A Commentary. Zv. 1b, 543-559. Oxford: Oxford University Press.

Cassese, Antonio. 2002. Crimes against Humanity. V: Antonio Cassese, Paola Gaeta in John R.W.D. Jones, ur. The Rome Statute of The International Criminal Court: A Commentary. Zv. 1a, 353-379. Oxford: Oxford University Press.

Griesser Pečar, Tamara. 2005. Cerkev na zatožni klopi: Sodni procesi, administrativne kazni, posegi ,ljudske oblasti’ v Sloveniji od 1943 do 1960. Ljubljana: Družina.

- - - 2010. Boj proti veri in Cerkvi (1945-1961). Ljubljana: Arhiv Republike Slovenije; Nadškofijski arhiv; Muzej novejše zgodovine Slovenije; Družina.

- - - 2013. Sodelavci iz duhovniških vrst: Udbovski priročnik razkriva nekatere metode, verske vojne' proti veri in Cerkvi. Slovenski čas, št. 41:2-3.
- - - 2017. Cirilmetodijsko društvo katoliških duhovnikov LRS in ,ljudska oblast' med najhujšo represijo. Bogoslovni vestnik 77, št. 2: 423-437.

Hančič, Damjan. 2015. Katoliški tabor v Ljubljani v primežu revolucionarnega nasilja leta 1942. Bogoslovni vestnik 75, št. 4:649-657.

Juhant, Janez. 2016. Ustrahovani narod na poti $\mathrm{k}$ resnici in svobodi. V: Marjan Maučec, ur. LETO 1945 - 70 let potem: monografija znanstvenih prispevkov, 130-141. Ljubljana: Državni svet Republike Slovenije.

Korošec, Damjan. 2009. Mednarodno kazensko pravo v KZ-1 (1.): Genocid. Pravna praksa, št. 22:18-19.

Mikola, Milko. 2012. Rdeče nasilje: represija v Sloveniji po letu 1945. Celje: Mohorjeva družba.

Piškurić, Jelka. 2018. Omejevanje svobode veroizpovedi v socializmu. Bogoslovni vestnik 78, št. 2:591-609.

Strajnar, Neža. 2014. Sodni procesi proti pripadnikom nekatoliških verskih skupnosti v obdobju komunizma v Sloveniji. V: Mateja Čoh, ur. Revolucionarno nasilje, sodni procesi in kultura spominjanja, 119-127. Ljubljana: Študijski center za narodno spravo.

Ščavničar, Darko. 2016. Procesi proti duhovnikom in redovnikom v mariborski škofiji od leta 1945 do 1951. V: Mateja Čoh Kladnik, ur. Brezpravje v imenu ljudstva, 111-127. Ljubljana: Študijski center za narodno spravo.

Zgaga, Sabina. 2009. Mednarodno kazensko pravo v KZ-1 (2): Hudodelstva zoper človečnost in vojna hudodelstva. Pravna praksa, št. 23:18-19. 